\title{
Revision of the Nynorsk standard: deliberation, decision and legitimisation
}

The planner proposes, but the community disposes

(Haugen 1966: 24)

\section{Introduction}

\subsection{Legitimacy and legitimisation}

Questions of legitimacy and legitimisation are at the very core of any standardisation project. At the end of the day, what really matters is whether people see the standard as a legitimate representation of their "language" and are willing to use it. How such legitimacy is obtained, however, may of course differ in different sociopolitical contexts and at different points in time. Another question - equally pressing - is whether people want to write their language at all or if they prefer using an exoglossic standard. One of the first steps in a standardisation process is thus to find out whether people actually think that they have a language worthy of written representation and that a standard would be worth using. This may, in some circumstances, turn out not to be the case. In that situation, one may seek to convince people of the value of a standardised written representation. Or one may, alternatively, refrain from the endeavour.

In situations where people and their languages have long been oppressed (cf. Lane this volume), establishing a standard may be a particularly difficult task. As a large body of research has shown, minority groups may not want to write their language, as it is not perceived as a useful vehicle for social mobility (e.g. Johansen 2013; May 2003; 2006). In other situations, people may not want a standard because creating a written or an oral standard almost inevitably will happen at the expense of diversity, as all possible forms and features of language in a community will not enter into the regulated standard (e.g. Oñederra this volume; Albury 2016 on Māori corpus planning). Standardisation, by necessity, implies the reduction of variation and the erasure of certain forms. If maintaining linguistic diversity is more important than establishing one authoritative written or oral standard, then agreement on what should constitute the standard is likely to be difficult, complex and perhaps undesirable. Also, similar issues may be at stake even in cases where a standard has existed for quite some time, such as the Norwegian minority standard Nynorsk.

In this paper I will discuss the most recent developments in Norwegian language policy and planning by considering the language reforms that took place, and 
were then implemented, just after the turn of the century (2005 and 2012). I will give particular focus to the revision of the Nynorsk standard as this process raised pertinent questions regarding top-down versus bottom-up approaches to language standardisation. An initially proposed revision attracted widespread grassroots objections and was ultimately rejected by the Ministry of Culture in 2005. When a new revision committee was appointed, broad societal representation and democratic legitimacy became central concerns in the standardisation process. In my paper I will consider the extent to which user-acceptance and legitimacy was reached through deliberative decision-making. Before entering into the details of present-day language planning in Norway, however, I will give an historical account of the written language situation.

\section{Historical background}

\subsection{Nation building - competing standards}

The written language situation in Norway has by some scholars been described as "schizoglossic", referring to the dual identity showcased by the Norwegian community for more than a century through the continuation of two written standards, Bokmål and Nynorsk (Haugen 1972). After 400 years under Danish rule (1396-1814), Norway gained independence in 1814 and a long-lasting language ideological struggle began. Denmark was on the losing side in the Napoleonic Wars, and was forced to give up Norway to Sweden. This gave rise to the Swedish-Norwegian union, which lasted until 1905 when it was dissolved peacefully. Within the new union, Norway had substantial political autonomy including a national assembly to enact laws and policies. Until 1814, Danish had been the exoglossic written standard in Norway, and this continued for most of the $19^{\text {th }}$ Century. Danish actually became more widely promoted in Norway throughout the 1800s, though under the name of 'Norwegian', due to the expansion of the school system and in order to strengthen Norwegian unity and delineate its language and culture from Swedish. As in many new nations at the time, however, Norwegian intellectuals and politicians argued for an endoglossic national written standard - distinct from Danish - given nationalism at the time saw national languages as pivotal to national identity and autonomy (e.g. Haugen 1966; Ammon, Negre, and Wright this volume; Wright 2004). The poet, linguist and founder of Nynorsk (previously Landsmål), Ivar Aasen, put it like this:

Since our fatherland has become what it once was, namely free and autonomous, it is imperative that we use an independent and national language, as this is the most distinguished hallmark of a nation. (Aasen 1836: 1) (my translation). 
Although some intellectuals wanted to keep Danish as the written language of Norway (but re-name it 'Norwegian'), most debaters wanted a new, Norwegian language. The different debaters, intellectuals and language planners did not, however, agree on which varieties of Norwegian would constitute the best and most proper basis for a new Norwegian written standard. Ivar Aasen proposed a norm based on a wide range of Norwegian rural dialects, as he saw these as the most authentic, unspoiled and true representation of the Norwegian language. He was not particularly fond of urban Norwegian dialects, perceiving these as contaminated by Danish (cf. Mæhlum and Røyneland 2011). The founder of Bokmål (previously Riksmål/DanoNorwegian), Knud Knudsen, on the other hand, proposed a gradual Norwegianisation of written Danish, based on the Dano-Norwegian variety spoken by the urban upper middle classes, the so-called 'educated daily speech'. Later, a wider range of spoken, particularly eastern Norwegian, varieties were also included (cf. Jahr 2003).

Since a parliamentary resolution in 1885 , the two standards have coexisted as legally equal written representations of Norwegian. While all Norwegians are required to learn both, Nynorsk has had a minority status since the very beginning in terms of number of users, power and prestige. Furthermore, the number of Nynorsk users has decreased substantially over the last 60 years, from approximately $35 \%$ of the Norwegian population in 1950 to approximately $13 \%$ in 2010 (cf. Grepstad 2015). Hence, today Nynorsk is used only by a small minority and is primarily associated with rural, West Norwegian culture, reflecting where it is primarily used (cf. Teigen 2001). The opposition between Nynorsk and Bokmål is linked to both regional (western Norway versus the rest of the country) and social (rural versus urban) allegiances. Each municipality may decide either to be neutral or to choose one of the standards as their main standard (see figure 1). As many as $26 \%$ of all Norwegian municipalities have chosen Nynorsk as their main standard, but since these municipalities are predominantly rural and thinly populated, the relative number of users is substantially lower.

Despite the regional divide, however, both standards are in principle national and not regional, and there are users of both standards across the country. Although the two standards may index different socio-cultural values and norms, they are not linked to different ethnic groups and they were never politicized to the extent that, for instance, Katharevousa and Dimotiki have been in Greece (e.g. Bucken-Knapp 2003; Jahr and Trudgill 1993; Mackridge 2009). As pointed out by Bucken-Knapp (2003: 13): "while language is a powerful group symbol in Norway, it has ranked behind both regional cleavages and the left-right divide". 


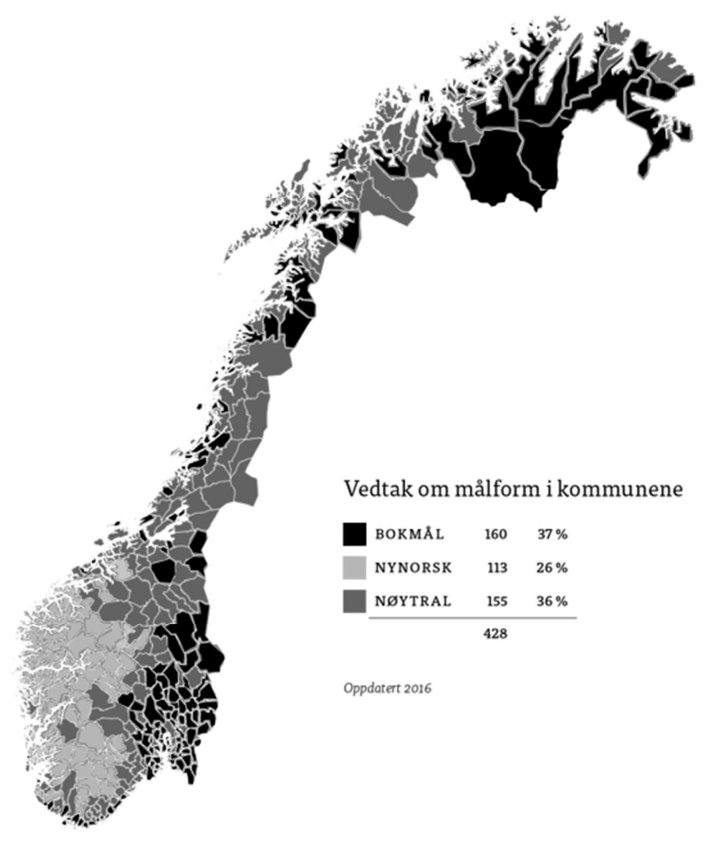

Figure 1: Main written standard in Norwegian municipalities, Bokmål (black), Nynorsk (light grey), neutral (dark grey) (Vikør 2016).

\subsection{Challenges for the minority standard}

As the minority standard, the existence and continued use of Nynorsk as an equal standard is under constant pressure. Does it really make sense to continue to use Nynorsk? Is it worthwhile? Would it not be more sensible to have all Norwegians use the majority standard? These questions are frequently posed both in academic discourse and in public debate, and are presumably questions that Nynorsk users also ask themselves. Language surveys show that approximately a third of those who received their instruction in Nynorsk later switch to Bokmål (cf. Garthus 2009; Grepstad 2015; Øvrelid 2014). In certain areas, as noted by Garthus (2009: 25), “To stick to Nynorsk is the conscious choice - to switch to Bokmål is to follow the crowd” (my translation). The argument in political debates and in the media is that in securing socioeconomic mobility, Bokmål serves you better than Nynorsk, mirroring arguments in minority language settings more broadly that "the perpetuation of minority languages is actively regressive - foreclosing the process of 'linguistic modernisation' for minority groups and the possibilities of social mobility for its individual 
members" (May 2003: 101) (but see May 2003: 112-114 for a criticism of this type of (im)mobility argument). ${ }^{1}$

The primary reason for the Nynorsk to Bokmål language shift is no doubt the inferior position Nynorsk holds vis-à-vis Bokmål, the dominance of Bokmål in the media, and negative attitudes towards Nynorsk (e.g. Thingnes 2015). However, people who have shifted to Bokmål often explain the shift as a consequence of Nynorsk allegedly being too difficult to write correctly. People seem to feel insecure about what the norm requires, and are afraid to make mistakes (Rødningen 1999; Garthus 2009). It also seems that in informal or private writing, such as text messaging to friends and family and writing in social media (like Facebook and chat), many people prefer to use their dialect (Garthus 2009; Rotevatn 2014).

\subsection{Corpus planning - policy of amalgamation}

Throughout the $20^{\text {th }}$ Century both Nynorsk and Bokmål were subject to numerous revisions (e.g. Jahr 2003; Røyneland 2013). ${ }^{2}$ Until the second half of the century the overarching goal was to merge the two standards into a single unified, panNorwegian written standard by using linguistic material from both rural and urban dialects (for comprehensive historical accounts and discussions see Bjørhusdal 2014; Bucken-Knapp 2003; Faarlund 2003; Haugen 1966; Jahr 2003; 2007; 2015). This policy was met with strong resistance by the Norwegian public and has long since been abandoned. Due to the so-called 'language struggle', there is great interest among Norwegians in language in general, and especially language policy and planning. There is a long tradition of debating language issues, not only amongst

1 One may, of course, argue that Nynorsk is not a minority language, but a minority standard. According to official policy, Nynorsk is one of two ways of writing Norwegian, a "målform", and not a language proper (e.g. Stortingsmelding 35, 2008, the most recent comprehensive policy document on language by the Ministry of Culture). Others contend that Nynorsk may be considered a proper language both on linguistic, historical and socio-political grounds (e.g. Bjørhusdal 2014). Nynorsk is not protected by the European charter - like Sami, Kven, and other territorial minority languages in Norway - since it is not considered a 'language' and since it is afforded the same rights as Bokmål by Norwegian law. For the sake of the present argument whether Nynorsk is considered a language or a standard does not have a significant bearing, and I will use both labels. However, when only regarded a standard, arguments of linguistic rights may be more easily dismissed and there may be a lack of understanding of why it is important to keep. Notwithstanding, it is widely recognised also in the aforementioned policy document - that Nynorsk is strongly linked to history, culture and identity for its users, and not merely an instrument for writing.

2 Language reforms in the 20th and 21st Century: 1901 (Nynorsk), 1907 (Bokmål), 1910 (Nynorsk), 1917 (both standards), 1938 (both standards), 1959 (both standards), 1980 (Bokmål), 2005 (Bokmål), 2012 (Nynorsk). The policy of amalgamation was particularly prominent in the 1917, 1938 and 1959reforms. During the 1980 this policy was gradually abandoned, but it was only officially given up in 2002. 
politicians and language activists but also amongst the public (cf. Linn 2010; Opsahl and Røyneland 2016; Røyneland 2013).

Despite Aasen using a wide range of rural dialects as the founding base for $\mathrm{Ny}$ norsk, he did not wish to establish a wide norm that would permit significant variation. Rather, his aim was a tight, invariant norm, "the language form should be one only" (Aasen 1958: 298, my translation). Hence, Aasen's goal was that "the standard language should represent the underlying system common to the dialects rather than individual forms from each dialect” (Faarlund 2003: 315). Knud Knudsen also desired a tight written norm. However, the policy of amalgamation, which was the overarching goal of several of the $20^{\text {th }}$ Century language reforms (particularly the 1917, 1938 and 1959 reforms), resulted in a great deal of variation within each of the official standards as the reforms aimed at mutual convergence by introduction of Bokmål forms into Nynorsk and vice versa. Both of the official standards obtained a great number of parallel forms (both in spelling and declination), and in 1938 a twolevel system of orthography was established within each of the written standards; a so-called restricted norm and a wider norm.

The restricted norm contained only the main forms and was obligatory in public administration and school textbooks. However, the main form was not necessarily unique; two or more parallel main forms could exist. The wider norm contained both main and subsidiary forms, and could be used by pupils, in newspapers, literature and in private writing. During the 1980s and 1990s, a number of dialect forms were also introduced into the Nynorsk standard (cf. Norsk språkråd 1998; Omdal and Vikør 1996). The justification was that Norwegian dialect diversity should be expressed through actual representation of different dialect forms such that people could appropriate a written language as close to their own dialect as possible. As pointed out by Faarlund (2003: 313), optionality was now no longer a means towards an end, but an end in itself. The amalgamating efforts combined with the subsequent inclusion of dialect forms resulted in a vast amount of parallel forms. ${ }^{3}$ Both standards became heterogeneous to the extent that one might identify two major varieties within each of them, forming a continuum from conservative Nynorsk through radical Nynorsk and radical Bokmål to conservative Bokmål.

Although the policy of unification by way of mutual convergence was gradually abandoned after the 1959 reform, it was only officially rejected in the early 2000s. At the beginning of the present century, Norwegian language policy took a new turn. Now, the goal was to reduce optionality within each of the written standards and to discard the two-level system. Within the Nynorsk community, however, disparate views and contradictory ideological stances exist about what an ideal norm should

3 The word 'possible' could for instance be written in six different ways: mogleg, [moglig], mogeleg, [mogelig], [muleg], [mulig]. The four bracketed form were subsidiary forms and two others main forms. After the 2012-reform only the main forms may be used (cf. Språkrådet 2011a: 55, 155; Røyneland 2013: 57). 
comprise. As noted by Vikør (2010), different views run along two main lines: the traditionalist view versus the convergence (towards Bokmål) view on the one hand, and the wide norm and freedom of choice (or pro-dialect) view versus the restrictive norm view on the other. In addition there are differences of degree along both dimensions - ranging from fairly categorical to more moderate and pragmatic views.

\section{The 2012-norm}

\subsection{Background}

On August 1st 2012 a new, revised norm for Nynorsk was implemented (henceforth the 2012-norm). This was the first major revision of Nynorsk since 1959. However, the Norwegian Language Council had initiated the reform process in 1996. Two separate expert committees of the Language Council were appointed to develop comprehensive orthographic reforms for both Bokmål and Nynorsk. In 2005, the Ministry of Culture approved a new norm for Bokmål. The Nynorsk reform proposal (henceforth the 2003-proposal), however, was met with major criticism in the consultative round and was eventually rejected by the Ministry.

The main political goal for the new reforms was, as noted above, to reduce optionality. Although the approved proposal for Bokmål still included a relatively wide range of freedom of choice between parallel forms, the degree of variation was substantially reduced, and the two-level orthographic system was repealed. One of the main objections against the 2003-proposal raised by the Ministry was that the twolevel system was not removed. Another important objection was that the 2003proposal did not have sufficient support within the Nynorsk community, as became evident in public hearings (for details see Fretland 2007; Røyneland 2013).

\subsection{New mandate and new committee}

In 2009, four years after the rejection of the 2003-proposal, a new reform committee was appointed. The mandate provided by the Language Council detailed the content of the new norm, the composition of the committee, and the conduct of the reform process. A key stipulation was that that the two-level system will be abandoned: "a clear, simple and restricted Nynorsk norm, without subsidiary forms" (Språkrådet 2011a: 27, my translation and italics). In addition the new norm would be a national and not a regional norm. Consequently it would be based on dialects nationwide and not be based on dialects from one specific region:

The norm should be such as to ensure that Nynorsk still appeals to language users all over the country and give room for variants that are commonly used by broad groups of Nynorsk users. 
A broad dialect foundation, commonly used variants and words, geographical spread, and the written tradition are thus amongst the most important factors that should be balanced in the new norm. (Språkrådet 2011a: 27, my translation)

The ironic situation is, therefore, that the mandate requires a more restricted norm but at the same time one that includes dialectal variation, ensures geographical spread, and is centred in the written tradition. As we will see below, these constraints conjointly create tensions that are not easily resolved.

A central proviso regarding the new committee was that it should comprise members from many different parts of society and have what was termed "high strategic norm competence":

The committee is put together with the intention of including members with high strategic norm competence at a national level, central linguistic expertise about modern language use, historical and practical experience from Nynorsk activist organisations and participation from the most important user groups and stakeholders. We have also taken gender and geographical belonging (place of birth and present residence) into account. (Språkrådet 2011a: 28, my translation).

The committee comprised seven members, all of whom had been active in Nynorsk policy issues one way or the other; a senior political advisor (leader), two teachers, two journalists, and two linguists. ${ }^{4}$ Different geographical regions were represented, and more importantly, different ideological stances were present in the committee (both traditionalist and convergence views, wide norm and restrictive norm views). Several of the members had in-depth knowledge about the Nynorsk grassroots, practical experience from different Nynorsk language interest organizations (e.g. Noregs Mållag, Norsk Målungdom, Mediemållaget), inside knowledge of the difficulties Norwegian elementary school children have in learning Nynorsk, and good insight into the resistance and prejudices Nynorsk encounters in Norwegian society at large.

The composition of the language committee was, however, met with considerable criticism - amongst other things for its lack of scientific competence, as only two of the committee members were linguists. Both Lunden (2010) and Faarlund (2010) argued that you don't ask truck drivers to construct a new road, you ask engineers; hence one ought to ask linguists to plan language, not its users. Replying to some of these reactions, a member of the previous language committee, Grønvik (2010), stated that the former committee's recruitment from "a narrow environment of

4 I served as the deputy leader of the reform committee. As a committee member I cannot, of course, claim to provide a disinterested evaluation. On the other hand, I believe this experience has been a source of useful and relevant insights, and has stimulated reflections that may be of use more generally. 
scholars and lexicographers" and "weak connection to society at large" was an important explanation for the 2003 proposal's lack of success:

To make changes in an established written standard is no simple matter, and is not only about orthographic principles and rules. I was part of the previous orthographic revision committee (2001-2003), which was a committee with strong scientific competence, but recruited from a narrow environment of scholars and lexicographers. The final result was that the committee was divided and both proposals were rejected. There were many reasons for this, but one, without a doubt, was the committee's weak connection to society at large. Neither the process nor the result was good enough. (Grønvik 2011, my translation).

To make changes in a norm is, as Grønvik argues, not only a matter of applying orthographic rules and principles. Proposed norm revisions have to be implemented by the principal social institutions and to be accepted by the community at large (cf. Haugen's fourth principle of language planning 1966). In other words, a reform proposal needs to be acknowledged as legitimate by its users. In order to ensure such legitimacy, Norwegian language policy makers saw it as important that the new reform committee include stakeholders from many different parts of society and that the reform process should be open and inclusive.

Legitimacy is no doubt a central concern for a reform committee, but how such legitimacy can be achieved may differ in different socio-political contexts and at different points in time. Scientific competence is one essential factor (as pointed out by Faarlund 2010), but at that particular moment it was probably not sufficient (see Ramberg this volume for a discussion of the transition from "epistocratic" (cf. Estund 2008) to democratic ideals and expectations). Other types of competence were seen as equally important. After a long process (starting in 1996 and ending in 2005) and a flawed proposal, it was critical to secure broad societal foundation - not only through the composition of the new committee, but also through the completion of the reform process itself. Nonetheless, the comprehensive and scientifically detailed 2003-proposal was an important working tool for the new committee.

In contrast to previous language reform processes during the 20th and 21st Century, the mandate of the committee was to ensure an open and inclusive process. The reform committee implemented this by arranging a number of consultations with central stakeholders, including principal Nynorsk institutions, companies and organization. The committee held 38 consultation sessions with Nynorsk publishers, translating firms, interest organizations, newspapers, teacher organizations, and universities. In addition, the committee established a web site and a discussion forum, where case documents and subsequent reports were published immediately before and after the meetings, hence people were able to follow the committee's work very closely and send reactions and feedback as the process was taking place. A total of 502 comments and suggestions were posted either on the discussion webforum or sent to the committee's email accounts in the course of the norm revision 
process. These contributions were introduced into the committee's discussions and contributed importantly to their substance.

Finally the reform committee presented a discussion document and arranged a public hearing where 380 participants took part (either physically or by webtelevision). The committee received 78 consultative submissions, which resulted in a 232-page document. As will be discussed more in detail below, the committee received many and often diverging views and reactions to its work. The different measures taken by the committee ensured that important stakeholders and the interested public had open access to the decision-making process all the way through. By contrast, in previous language reform processes the public had the opportunity to react only to a more or less completed norm revision proposal. An important question and a decisive factor in securing broad acceptance, however, concerns the extent to which the features intended to ensure the open and dialogical character of the reform process in fact had a real impact on the very substance and content of the proposal. We will return to this critical question below.

\subsection{Challenges in the mandate}

A critical examination of the mandate, makes it evident that the committee's task was not always entirely clear, nor free from internal tensions. As I have discussed and demonstrated elsewhere, the requirements clear and simple, on the one hand, and restricted, on the other, may, for instance, be conflicting in specific cases - a point that was subject to much discussion in the reform committee (Røyneland 2013: 61). Although the reduction of orthographic choice may facilitate people's learning and present a firmer basis for leaning to write correctly (cf. Faarlund 2003: 314), there are cases where the opposite might transpire. ${ }^{5}$ Also, the requirement that it be a national and not a regional norm, a more restricted norm and the same time a norm that includes dialectal variation, is not easily reconciled (for a detailed discussion of the mandate see Røyneland 2013). In view of the potential conflicts between the different considerations, the committee made a list of priorities in order to carry out its assignment:

5 One example of this may be found in noun inflexional system. Most feminine nouns have the plural indefinite and definite suffixes -er/-ene. However, certain single syllable feminine nouns have -ar/-ane as main forms and [-er-ene] as subordinate forms. The question was whether the norm would become simpler and easier to learn if these subordinate forms were omitted, or, alternatively, if they were paralleled with the main suffixes. In this case the committee's assessment was that having the opportunity to apply the main paradigm in these single syllable nouns as well, that is er/-ene, would be easier than to eliminate it since it represents a simplification of the system. Hence, both suffixes were included in the new norm, and "simple", interpreted as possible reduction of irregularity, was chosen before "restricted", understood as a reduction of possible choice (Røyneland 2013: 61-62). 
1. The norm should have an independent foundation, that is, independent of Bokmål

2. Nynorsk written tradition and practice should have priority over dialectal variation and particular emphasis should be placed on the contemporary use of Nynorsk

3. Geographically widespread dialect features should be attributed weight

4. Lesser used variants should, as a rule, be removed from the norm, whereas variants that are frequently used should be kept and juxtaposed

According to the first point in the prioritized list, the independent foundation, it should neither be an advantage nor a disadvantage for a given variant that it be part of the Bokmål standard. This guideline was, however, not always easy or even possible to meet, given Nynorsk's position as a minority language (Røyneland 2013: 60).

The second point on the priority list was that the reform process should focus on the Nynorsk written tradition and practice as it has evolved over the centuries and place particular emphasis on contemporary use of Nynorsk. To help determine empirically which variants are most commonly used in contemporary Nynorsk, the committee had at its disposal a recently developed tool that was not available to the previous reform committees: a searchable, balanced corpus of 87 million words from written Nynorsk texts that covers a wide range of different genres and includes texts from the end of the 19th Century up until today (The Nynorsk text corpus at the University of Oslo). The main body of the corpus, however, (approximately $80 \%$ ) consists of contemporary texts from the 1980s and forward. This gave the committee a firmer basis on which to make its decisions compared to previous committees. The goal was to approximate what has been labelled a "centreline" Nynorsk, that is, the combination of variants that the majority of Nynorsk users actually apply in their writing (cf. Vikør 2009; 2010).

Thirdly, geographically widespread dialect variants should be attributed weight. To help determine which variants are geographically widespread, the committee had available a big body of dialectological research in addition to a searchable dialect corpus from 100 different locations in Norway (The Nordic Dialect Corpus at the University of Oslo - also not available to previous committees).

Fourthly, lesser-used parallel main or subsidiary forms should, as a main rule, be excluded from the norm, whereas main or subsidiary forms with a relatively high standing (either in writing or in the dialects) should be retained. All these requirements were part of the mandate, but the point here was to make a prioritised list that could be helpful in cases where different requirements diverged.

An additional requirement put forward in the mandate was that the new norm should make it easier to be a user of Nynorsk regardless of education and linguistic competence, and it should be clear to all who use Nynorsk as their secondary language. The idea that a norm revision by itself can make it easier to be a user of a minority standard is questionable. The underlying assumption of this requirement 
seems to be that it is difficult to use the Nynorsk norm due to the high number of parallel forms. While this may be the case, the real challenge most likely lies elsewhere. ${ }^{6}$

\section{Democratic deliberation and legitimacy}

\subsection{Democratic deliberation}

The democratic nature of the 2012 reform was emphasised by several parties - not least by the Language Council and the head of the Council Board. This cannot, of course, be regarded as a disinterested opinion, but the evaluation of the process and the committee's work is still illuminating in that it makes explicit the standard by which the process is to be assessed:

This may not be the most comprehensive Nynorsk language reform, but it is the most democratic, and probably also the most important. (Grepstad 2011b: 1, my translation)

The work with the 2012 norm may well stand as a model for current practices of social change, illustrating how processes of this kind may lead to wise decisions on difficult issues where opinions diverge widely. (Språkrådet 2011c, my translation).

However, we must ask how we are to understand the notion of a democratic process. If the process is accepted as democratic does that automatically ensure that the result is accepted as legitimate? Recent work in democratic theory focussing particularly on the nature of deliberative democracy provides useful tools for addressing this question (see Ramberg this volume for further discussion of deliberative democracy).

The notion of deliberative democracy was originally coined by Bessette (1980), but the main ideas go back the works of Habermas and Rawls. Some practitioners

6 What really would make a substantial difference and make it easier to use Nynorsk, is if attitudes towards Nynorsk were more favourable, and if state institutions actually tried to fulfil their obligation (by law) to use $25 \%$ Nynorsk in their official writing - which regrettably is far from the actual situation (Språkstatus 2012). Even within higher education Nynorsk users experience prejudice and have to fight for their rights - for instance to get their exams in Nynorsk. Quite recently a Facebook picture of an exam given to a student at the Norwegian University of Science and Technology triggered a heated debate in the media (cf. Bjørdal 2016; Vangsnes \& Solheim 2016a; 2016b). The text was riddled with errors and written in what best can be described as mock-Nynorsk. The fact that the linguistic quality of texts written in Nynorsk is not taken seriously enough is supported by a recent study at the University of Oslo. The study revealed that the linguistic quality of the exams given in Nynorsk was objectionably low, and that many faculties had no system of securing the quality of the assessments (Thingnes 2015). An abundance of errors sometimes made the exams difficult to understand. 
and theorists use the term to encompass representative bodies whose members with equal distributions of power authentically deliberate on legislation, while others use the term exclusively to refer to decision-making directly by lay citizens, as in direct democracy. I use it in the first sense here, not in the sense of populist democracy where pure numbers are what counts, but in the sense of true deliberation between competing, diverging views by a representative body.

The notion of representation here carries a great deal of weight and, unsurprisingly, is the subject of much discussion. As Dryzek (2010) points out, most deliberative theorists have developed conceptions of deliberative systems that are, "tied to the institutional details of developed liberal democracies” (Dryzek 2010: 10). However, as Dryzek argues at length, the basic idea of legitimation through deliberation can be given much wider application. In particular the idea of representation need not be tied to the institutional systems of liberal democracies, but may be generalized to a variety of social and political contexts. In our case, however, the selection of the reform committee was performed by an official state institution, i.e. the Language Council, and the process was initiated and sanctioned by the Ministry of Culture, a central institution in our democratic, parliamentary system. The democratic nature of these institutions themselves, while admittedly a condition of the legitimacy of the entire process, will not be subject to discussion here but will be taken for granted. Still, in political theory, the notion of legitimacy is applied both to decision-making processes and decision-making bodies. Thus one might raise questions of legitimacy both of the composition of the working group itself, and of the actual process of work leading to the proposal. The first of these issues has already been addressed, and I will remark on it only briefly, before considering at somewhat greater length criticism that place in question the legitimacy of the actual process of deliberation and its result.

The reform committee engaging stakeholders from across Norwegian society with diverging ideological stances (cf. section 3.2. above), is in line with what Dryzek (2010) calls discursive representation. That is, ensuring that the disparate views and different orientations within the Nynorsk community at large are reflected, as far as is practically possible, in the deliberations of the committee itself. The extent to which such representation is achieved - both with regard to the fineness of grain and the width of the spectra of differences of views - is unavoidably constrained by other aims and needs. Ensuring a workable size of the group, a reasonably timely process, and, not least, the prospect of a conclusive outcome, may curtail the demand for discursive representation along both these lines. On this score, then, a working committee of this sort will always be open to challenge, as indeed happened (e.g. Faarlund 2010; Lunden 2010; Norsk Måldyringslag and Ivar Aasen sambandet 2011). However, it will not be my concern here to assess the validity of these particular objections against the composition of the committee or its mandate. That is, of course a valid, but still a different discussion than the one I want to pursue 
here. Rather, my question is to what extent the deliberative process as it unfolded satisfies the demands of democratic deliberation.

To bring this issue clearly into view it will be helpful to consider the actual responses to the proposal. In some cases these responses are critical of the mandate as well as of the composition of the group, but for our purposes it will be important to distinguish those points that pertain specifically to the process and its ability to confer legitimacy on the result. Although some stakeholders were critical of the mandate and the language policy objectives behind it, most stakeholders seemed to agree that a Nynorsk language reform was necessary and a reduction of forms desirable (only not which forms).

\title{
4.2 Democratic process and result?
}

In the final consultative round, all major institutions and interest organisations supported the 2012-proposal and acknowledged the process and its result as legitimate, even if they did not agree on every point, as stated here by the chair of the board of the Language Council:

\begin{abstract}
Amongst the members of the board and the advisory board for norm revision at the Language Council, within the revision committee itself, as well as amongst the users of Nynorsk in general, opinions vary on individual measures. Still Nynorsk users are closer to a certain consensus in the question of orthography than ever before. The central Nynorsk institutions that have stated their opinion, support the main features of the proposal, none of them has objected on the basis of principle. (Grepstad 2011a, my translation)
\end{abstract}

Similar assessments were offered by a number of public stakeholders, for instance the board of the biggest Nynorsk interest organisation (Noregs Mållag), and the University of Bergen (for details see Røyneland 2013: 69-70). However, critics from both the traditionalist camp and the convergence (towards Eastern Norwegian/Bokmål) camp diverge from this assessment. From opposite ends of the ideological spectrum, these have seriously questioned the allegedly democratic process. In a detailed and massively critical response to the 2012 reform two relatively small, traditionalist organisations argued that the proposal was undemocratic and the process behind it opaque. These organisations claimed that the principles underlying the committee's work were not made clear nor open to discussion, and that their voices, in particular, were dismissed and not taken into account. Hence they criticised the reform process and question its democratic status in light of the final result:

It is the marginal status that the traditional forms were forced into in 1938, which the reform committee now uses as an argument to tear down the foundation for the Nynorsk language system. There has not been even a trace of a discussion about this, and consequently there is no democratic nor procedural foundation of the new reform proposal. [...] The work on the new or- 
thographic reform has been one-sided all the way. Traditionalist voices have consciously been kept out, and have no part in the present proposal. The committee has only opened for discussion about cosmetic insignificancies. [...] The process has been one-sided, but without the real presuppositions of the work having been made visible to the general public. The opposition from traditionalists has been put aside and ridiculed in spite of the extreme rhetorical focus on an 'open process'. (Norskt Måldyrkingslag and Ivar Aasen-sambandet 2011: 37-38, my translation).

The charge made by the traditionalists is that the actual process of deliberation through which the proposal was developed precluded the result's legitimacy because it systematically excluded voices with a legitimate claim. Thus, on this view, there is a discrepancy between the presupposition of inclusivity, essential to the legitimacy of the eventual outcome, and the perceived content and dynamics of the process. One of their main complaints was that linguistic forms that were "forced" into a marginal position in 1938 are not given due consideration. On their diagnosis, the committee has systematically excluded from discussion a valid and relevant perspective on the nature of Nynorsk and the history of its standardisation - thus the process was compromised, as it was not discursively representative.

Attacks on the process by those who disagreed with the outcome is not an unexpected move, given the emphasis placed on democratic deliberation, openness and inclusiveness. Since it was known from the outset that no stakeholder was likely to be happy with all aspects of the reform package, damaging criticism must do more than register dissent on specific aspects or decisions. A serious attempt to undermine the reform process would require evidence that the process was so flawed that the outcome cannot stand as a legitimate deliberative mediation of competing perspectives and interests. In the present case, the traditionalist critics are right in their claim that the conception of Nynorsk that they promote was not treated as a serious option. However, can this point fairly be taken as a criticism of the process of deliberation itself? We should keep in mind here that the committee was instructed by the mandate to take the 2003-proposal as the founding document for its work and to place particular emphasis on contemporary language use (written and oral) (Språkrådet 2011a: 27; see discussion in section 3.3). In this light, the traditionalist criticism appears to be a criticism of the political mandate, rather than of the legitimacy of the procedural deliberations carried out by the committee within the mandated terms. This is not to say that critique of the mandate itself is not legitimate per se, only that it must be kept distinct from the assessment of the legitimacy of the process in so far as it is based on the mandated premises.

At the other end of the ideological spectrum, Fosse (2011), a supporter of the inclusion of Eastern Norwegian forms in Nynorsk, also criticises the reform process and questions its democratic status in light of the final result:

The democratic process of the language reform proposal is highlighted, not least by the chairman of the Language Council. But is it enough to be allowed to present your opinions, if these opinions are not taken into account? Many of the consultative submissions were negative to- 
wards the removal of eastern Norwegian forms [...]. The reform committee has only to a very small extent made adjustments in its final proposal. (Fosse 2011, my translation).

A pressing question here is what "taken into account" actually means, and how it might be demonstrated through procedural fairness. Discursive representation requires, of course, not only that all pertinent views are presented, but, crucially, that they are heard - that they have the opportunity to rationally affect the outcome. It could not, however, require that all views prevail since the very point is to decide between views in conflict. Fosse, however, appears to argue that unless the responses and suggestions put forward have direct and verifiable impact on the final result, there is no evidence that they have indeed been taken into account. If we follow this argument, it would seem that a great many of the different opinions presented at the consultations were not accepted as significant, and that the process, accordingly, was democratic only in appearance. In cases where several stakeholders' views converge it is easier to show how input to the committee changed the reform proposal.

One specific example of this is the committee's suggestion to remove the socalled split infinitive from the norm. The two-level Nynorsk standard allowed three different infinitival endings: two parallel main forms - $a$ or -e (kasta, vera or kaste, vere 'throw', 'be') and a subsidiary system where the infinitival ending would shift between $[-a]$ and $[-e]$ in accordance with the principle of the so-called syllable balance rule (kaste vs. vera). This subsidiary system has, however, almost fallen out of use in contemporary written Nynorsk and is currently in decline in many of the dialects that used to have it (for a more detailed discussion see Røyneland 2013: 6667). Still, the committee's suggestion to remove the split infinitive and only allow the two parallel main forms was met with resistance from many different stakeholders both during consultations and previously, and as a consequence the committee decided to keep all three variants in the final proposal. However, in situations where there are many different and often opposing views it may be hard to demonstrate convincingly that true deliberation has taken place. Thus, the result of a deliberative balancing process will typically be that some stakeholders - particularly those on the opposite poles of the ideological spectrum - experience that their voice was not heard, that their particular views were not given due consideration, and thus did not have the intended impact on the final outcome. This perception will often, and quite understandably, lead stakeholders to view the process as illegitimate. The question is, however, how are we to interpret and evaluate such assertions.

What makes the criticism put forth by Fosse pertinent is not so much her disagreement with the content of proposal. The point of her criticism - as with that of the traditionalists - aims to undermine the legitimacy of the proposal, claiming that relevant views were not afforded fair hearing in the process. On the face of it, then, these kinds of objections are worrying. At the same time, however, transparent policy-making procedures cannot disallow negative reactions. Their merit and their 
significance, it seems to me, will depend on how widespread they are, and, in particular, on whether or not such challenges are made from a variety of incompatible positions on the matter to be resolved. How might we go about deciding whether such criticism itself has a legitimate claim to be heeded? A definitive answer is probably not possible, but perhaps some light may be shed on the question by the concept of meta-consensus, introduced and discussed at length by Dryzek (2010).

A meta-consensus, in brief, reflects the willingness of parties to put aside disagreement on specifics - to sacrifice some of their own concrete preferences - in order to realise an overarching agreement, on a set of general terms to which all parties are committed. The strength of this idea is that it allows us to maintain the genuine commitment to pluralism of values and differences of views while providing us with a means of reaching operative agreement. The question to ask, then of the criticisms we have just broached, is how they stand with respect to the metaconsensus - most succinctly stated in the mandate - that govern the deliberations leading to the new proposal. Are they a part of that common understanding of the decision task that was to be undertaken? If they are not, do they show that the operative meta-consensus itself is flawed - perhaps too narrow, or excluding, or ideologically biased? Neither of these questions may be easy to decide, but they indicate a direction for assessing the force of criticisms that challenge the basic legitimacy of the proposal. Here the standard of assessment must be pragmatic - if the metaconsensus expressed by the mandate is clear enough, strong enough, and inclusive enough to support a sufficiently inclusive and open deliberative process, then this is all we can reasonably ask. If the evidence on balance suggests that this is so, then the claim to genuine openness and to democratic authority may still be sustained (cf. Estlund 2008), even in the face of disagreement and challenge.

\section{Concluding remarks}

The essence of deliberation is that there is a fundamental difference between democracy by counting and democracy by consideration of arguments. First different arguments and viewpoints must come forward, and next there must be a competent and legitimate body that can deliberate. In a democratic process, a crucial task is precisely to try to balance different opinions, not by sheer quantitative weighing of responses, but by considering and comparing the merits of competing views. Or as John Stuart Mill aptly frames the challenge in his Considerations of Representative Government (1861), "One of the two, as the wiser or better man, has a claim to superior weight: the difficulty is in ascertaining which of the two it is" (here after Estlund 2008: 1). The result of this balancing will typically be that some stakeholders experience that their voice was not heard, that their particular views were not given due consideration. I have suggested that to be able to move toward substantive deci- 
sions on contested issues, deliberation must be informed by a meta-consensus, representing terms of procedure and a framework of compromise to which all are committed. In reality, though, such consensus will neither be completely clear nor universal. As we have seen, this is certainly true of the mandate for work of the reform committee. Thus, it is to be expected that such processes will be challenged, and their legitimacy placed in question.

Eventually, the success of a language standard rests upon the extent to which it is used. Hence, the evaluation of the most recent Nynorsk revision is contingent on its application by the Nynorsk community. The fact that most public stakeholders were in support of the new norm, vouches for its use by large groups of Nynorsk users. However, the critical reactions that we have just considered suggest that some user groups find that their "language" is not reflected in the new norm. Consequently they do not regard it as a legitimate representation of Nynorsk, and are likely to refrain from using it. Since Nynorsk is a minority language, and the number of users is decreasing, this would of course not reflect the intention of the norm revision. An important goal of the revision was precisely to come up with a standard that would accommodate as many users as possible. My view is that this is a strong consideration in favour of a usage-based, centre-line-oriented norm for Nynorsk. On this point, however, the future is the only judge.

\section{References}

Aasen, Ivar. [1836] 1909. Om vårt skriftsprog [About our written language]. Syn og Segn 17, 1-5.

Aasen, Ivar. 1958. Brev og Dagbøker [Letters and diaries], Vol. 2. Oslo: Samlaget.

Albury, Nathan. 2016. An old problem with new directions: Mãori language revitalisation and the policy ideas of youth. Current Issues of Language Planning, Vol. 17, Issue 2, 161-178.

Bessette, Joseph M. 1980. Deliberative democracy: The majority principle in republican government. In Robert A. Goldwin and William A Shambra (eds.), How Democratic is the Constitution?, 102-116, Washington, DC: AEI Press.

Bjørdal, Sesilie. 2016. Risikabelt å skrive Nynorsk? [Risky to write Nynorsk?] NRK Ytring 18.06.2016. Bjørhusdal, Eli. 2014. Mellom nøytralitet og språksikring: Norsk offentleg språkpolitikk 1885-2005. [Between neutrality and language securement: Official Norwegian language policy 1885-2005]. Oslo: University of Oslo dissertation.

Bucken-Knapp, Gregg. 2003. Elites, language, and the politics of identity. The Norwegian case in comparative perspective. Albany NY: State University of New York Press.

Dryzek, John S. and Simon Niemeyer. 2010. Foundations and frontiers of deliberative democracy. Oxford: Oxford University Press.

Estlund, David. 2008. Democratic Authority. A Philosophical Framework. Princeton N): Princeton University Press.

Faarlund, Jan Terje. 2003. The Nynorsk standard language and Norwegian dialect varieties. In Social dialectology: In honour of Peter Trudgill [Impact: Studies in Language and Society 16], David Britain \& Jenny Cheshire (eds.), 311-325. Amsterdam: John Benjamins.

Faarlund, Jan Terje. 2010. Språknormering er fagarbeid. [Language revision is work of professionals]. Dag og Tid (15 January 2010). 
Fosse, Tordis Irene. 2011. Færre austnorske former i nynorsken. Brev til styret i Språkrådet, 18. mai 2011 [Fewer Eastern Norwegian forms in Nynorsk. Letter to the executive committee of the Language Council, May 18th]. http://www.sprakradet.no/upload/Rettskrivingsnemnda/ Høyringsutsegner/Fosse.pdf (accessed 9 May 2016).

Fretland, Jan Olav. 2007. Aldri har så mange skrive så mykje for så lite...? Om ti års arbeid med nynorsknormalen [Never have so many written so much for so little...? On ten years work with the Nynorsk orthography]. In Gunnstein Akselberg and Johan Myking (eds.), Å sjå samfunnet gjennom språket [To see society through language], 63-73. Oslo: Novus.

Garthus, Karen Marie Kvåle. 2009. Rapport om språkskifte i Valdres. [Report on language shift in Valdres] http://www.nm.no/_filer/rapport_om_spraakskifte_i_valdres.pdf (accessed May 2016).

Grepstad, Ottar. 2011a. Språkrådet støttar ny nynorskrettskriving. [The Language Council supports new Nynorsk orthography] http://www.sprakradet.no/Spraka-vare/Norsk/Rettskrivingsreformer/nynorsknorm/bekgrunn/Nyheiter/Sprakradet-stottar-ny-nynorskrettskriving/ (accessed May 2016).

Grepstad, Ottar 2011b. Ein språknormal for lang tid [A language norm for the future]. http://www.sprakradet.no/upload/Rettskrivingsnemnda/OG\%20tale\%20Høyring\%20innleiin g\%2020110221.pdf (accessed May 2016).

Grepstad, Ottar. 2015. Språkfakta. Ei forteljing om språk i Noreg og verda gjennom 850 tabellar. [Language facts. A story about language in Norway and the world through 850 tables]. Volda: Nynorsk kultursentrum.

Grønvik, Oddrun. 2010. Nynorskrevisjon for framtida - eit svar til Kåre Lunden [Revision of Nynorsk for the future - answer to Kåre Lunden]. Dag og Tid (30 April 2010).

Haugen, Einar. 1966. Language conflict and language planning: The case of modern Norwegian. Cambridge MA: Harvard University Press.

Haugen, Einar. 1972. Schizzoglossia and the linguistic norm. In Dil, Anwar S. (ed.): The ecology of language: essays, 148-158. Stanford: Stanford University Press.

Jahr, Ernst H. \& Peter Trudgill. 1993. Parallels and differences in the linguistic development of modern Greece and modern Norway. In Ernst H. Jahr (ed.), Language conflict and language planning, 83-113. Berlin/New York: Mouton de Gruyter.

Jahr, Ernst Håkon. 2003. Norwegian. In Ana Deumert and Wim Vandenbussche (eds.), Germanic standardizations: Past to present [Impact: Studies in Language and Society 18], 331-355. Amsterdam: John Benjamins.

Jahr, Ernst Håkon. 2007. The planning of modern Norwegian as a sociolinguistic experiment - 'from below'. In Stephan Elspaß, Nils Langer, Joachim Scharlith and Wim Vandenbussche (eds.), Germanic language histories 'from below' (1700-2000), 379-405. Berlin: Walter de Gruyter.

Jahr, Ernst Håkon. 2015. Språkplanlegging og språkstrid : utsyn over norsk språkhistorie etter 1814. [Language planning and language struggle: views of Norwegian language history after 1814]. Oslo: Novus.

Johansen, Åse Mette. 2013. Overcoming silence: language emancipation in a coastal SámiNorwegian community. Sociolinguistic Studies Volum 7 (1-2): 57-77.

Linn, Andrew R. 2010. Voices from above - voices from below. Who is talking and who is listening in Norwegian language politics? Current Issues in Language Planning 11(2): 114-129.

Lunden, Kåre. 2010. Lett nynorsk for alle i heile landet [Simple Nynorsk for everyone in the country]. Dag og Tid (23 April 2010).

Mackridge, Peter. 2009. Language and National Identity in Greece 1766-1976. Oxford: Oxford University Press.

Mæhlum, Brit \& Unn Røyneland. 2011. “Lasternes Hule” eller “Civilisationens Arnested”? Byens posisjon i norsk talemålsforskning [“A den of iniquity” or "The hotbed of civilisation"? The po- 
sition of the city in Norwegian dialectology]. In Jon Gunnar Jørgensen \& Lars S. Vikør (eds.), Nordiskfaget - tradisjon og fornying [Nordic studies - tradition and renewal], 69-96. Oslo: Novus Forlag.

May, Stephen. 2003. Rearticulating the case for Minority Language Rights. Current Issues in Language Planning 4(2): 95-125.

May, Stephen. 2006. Language policy and minority rights. In Thomas Ricento (ed.), Language policy. Theory and method, 255-272. Malden, Oxford \& Carlton: Blackwell Publishing.

Ministry of Culture. 2011. Godkjenning av nytt rettskrivingssystem i nynorsk [Letter of approval of the new orthographic system of Nynorsk]. http://www.sprakrad.no/upload/spraknytt/ Godkjenning\%20av\%20nytt\%20rettskrivingssystem\%20i\%20nynorsk.pdf (accessed 20 January 2016).

Noregs Mållag 2011. Høyringssvar frå Noregs Mållag om ny nynorsk rettskriving [Consultative submission from Noregs Mållag concerning new orthography for Nynorsk]. http://www.sprakradet.no/Spraka-vare/Norsk/Rettskrivingsreformer/nynorsknorm/ bekgrunn/Hoyring/ (accessed 5 June 2016).

Norsk språkråd, 1998. Ordtilfanget i nynorsk - synsmåtar og røynsler. [Vocabulary in Nynorsk views and experiences]. Oslo: Norsk språkråds skrifter.

Norskt Måldyrkingslag and Ivar Aasen-sambandet 2011. Analyse av arbeidet med ny rettskriving for nynorsk- Notat til Kulturdepartementet. [Analysis of the work on the orthographic reform for Nynorsk - Memorandum to the Ministry of Culture] http://www.ivaraasen.no/vitring/rettskrivdept.pdf (accessed 3 May 2016).

Omdal, Helge \& Lars S. Vikør. 1996. Språknormer i Norge. Normeringsproblematikk i bokmål og nynorsk [Language norms in Norway. Standardization issues in Bokmål and Nynorsk]. Oslo: Cappelen Akademisk Forlag.

Opsahl, Toril \& Unn Røyneland. 2016. Reality rhymes - recognition of rap in multicultural Norway. Linguistics and Education. Available online 13 July 2016.

Øvrelid, Iselin Nevstad. 2014. Språkskifte ved tre vidaregåande skular i Møre og Romsdal. Påverknad og haldningar. [Language shift at three high schools in Møre and Romsdal. Impact and attitudes.] Volda: University College Volda MA-thesis.

Rødningen, Dagfinn. 1999. Ottadalen - ein utforbakka til Bokmålet? Språkproblem og språkskifte blant ungdom i Lom, Sjåk og Vågå [Ottadalen - a descent to Bokmål? Language problems and language shift among adolescents in Lom, Sjåk og Vågå]. In Turid Kleiva, Ingeborg Donali, Tryge Nesset \& Helen Øygarden (eds.), Austlandsmål i endring [Eastern Norwegian in change], 246-258. Oslo: Samlaget.

Rotevatn, Audhild G. 2014. Språk i spagaten. Facebook-språket. Om normert språk og dialekt blant vestlandselevar [Language doing the splits. Facebook language. On standard language and dialect among pupils in Western Norway.] Volda: University College Volda MA thesis.

Røyneland, Unn. 2013. "The voice from below": Norwegian language reforms in the 21st century. In Terje Lohndal (ed.), In search of universal grammar: From old Norse to Zoque, 53-76. Amsterdam: John Benjamins.

Sandøy, Helge. 2003. Den norske normeringssirkelen. [The Norwegian standardisation circle]. In Helge Omdal and Rune Røsstad (eds.), Krefter og motkrefter i språknormeringa. Om språknormer i teori og praksis. [Forces and counter-forces in language standardisation. On language norms in theory and practice], 259-271. Kristiansand: Høyskoleforlaget.

Språkrådet 2011a. Ny rettskriving for 2000-talet. Rettskrivingsnemnda for nynorsk. Innstilling, april 2011 [New orthography for the 21st Century. Language reform committee for Nynorsk. Proposal, April 2011]. 
Språkrådet 2011b. Språkrådet støttar ny rettskriving [The Language Council supports new language reform] http://www.sprakradet.no/Spraka-vare/Norsk/Rettskrivingsreformer/nynorsknorm/ bekgrunn/Nyheiter/Sprakradet-stottar-ny-nynorskrettskriving/ (accessed 10 June 2016).

Språkrådet 2011c. Tilråding om ny rettskriving. Brev til Kulturdepartementet dagsett, 26.05.2011 [Recommendation concerning new orthography. Letter to the Ministry of Culture, 26 May 2011] http://www.sprakrad.no/upload/-Rettskrivingsnemnda/Brev (accessed 10 June 2016).

Språkstatus 2012. Språkpolitisk tilstandsrapport frå Språkrådet. [Language policy report from the Norwegian Language Council] http://www.sprakradet.no/upload/Språkstatus/Språkstatus \%202012.pdf (accessed 10 June 2016)

Stortingsmelding 35. 2008. Mål og Meining. Ein heilskapleg norsk språkpolitikk. Kultur- og kyrkjedepartementet. [Language and meanings. A comprehensive Norwegian language policy. Ministry of Culture] https://www.regjeringen.no/no/dokumenter/stmeld-nr-35-2007-2008/id519923/ (accessed 10 June 2016).

Thingnes, Jorunn. 2015. Skriftmangfald på norsk: språkforvaltning, normbrot og språkhaldningar [Written diversity in Norwegian: language management, norm violations and language attitudes]. Oslo: University of Oslo MA-thesis.

Universitetet i Bergen 2011. Høyringsfråsegn om revisjon av nynorskrettskrivinga [Consultative submission about revision of the Nynorsk orthography]. (24 February, 2011).

Vangsnes, Øystein \& Randi Solheim. 2016a. Liksom-nynorsk og språklege rettar [Mock-Nynorsk and language rights]. Universitetsavisa.no (June 7, 2016)

Vangsnes, Øystein \& Randi Solheim. 2016b. Språklege rettar - og plikter. [Language rights and obligations.] Universitetsavisa.no (June 15, 2016)

Vikør, Lars S. 2009. Om normering av nynorsk på tidleg 2000-tal - Behov eller trong? [On revision of Nynorsk in the early 21st Century - Need or desire?]. In Språknormering - i tide og utide? [Language revision - timely or untimely?] Helge Omdal and Rune Røsstad (eds), 269-281). Oslo: Novus.

Vikør, Lars S. 2010. Om normering av nynorsk. Foredrag på opningskonferanse i Språkrådet, 20.01.2010 [On revision of Nynorsk. Paper held at the opening conference of the Norwegian Language Council January 20th, 2010).

Vikør, Lars S. 2016. Språk i Norge. Store norske leksikon https://snl.no/nynorsk (accessed 20 May 2016).

Wright, Sue. 2004. Language Policy and Language Planning: From Nationalism to Globalisation. New York: Palgrave. 
Bereitgestellt von | UiO - Universitetsbiblioteket 